\title{
Prolonged Blood Storage Does Not Effect Survival in an Animal Model of Hemorrhagic Shock
}

\author{
Uri Abadia,b* Gabriel Butenero ${ }^{c^{*}}$ Tania Kogan ${ }^{\mathrm{d}}$ Ofer Ziv ${ }^{\mathrm{b}}$ Haim Paran ${ }^{\mathrm{b}, \mathrm{c}}$ Martin H. Ellis ${ }^{\mathrm{a}, \mathrm{b}}$

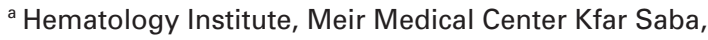 \\ ${ }^{\mathrm{b}}$ Department of Medicine Sackler School of Medicine, Tel Aviv University, 'Department of Surgery 'A', \\ ${ }^{\mathrm{d}}$ Pathology Institute, Meir Medical Center Kfar Saba, Israel
}

\section{Keywords}

Transfusion · Storage time $\cdot$ Shock $\cdot$ Resuscitation

\section{Summary}

Background: Red blood cell (RBC) transfusion in hemorrhagic shock is life saving. However, several clinical trials have shown that blood transfusion in the critically ill patient might be associated with adverse outcomes. Furthermore, an association between prolonged blood storage and adverse effects of RBC transfusion has been postulated. The aim of this study is to examine the effect of blood storage time on resuscitation outcome, in an animal model of hemorrhagic shock. Methods: 20 Wistar rats were phlebotomized in order to induce reversible hemorrhagic shock. Half of them were resuscitated with blood stored for a short period of time (4 days), and the other ones were resuscitated with blood stored for a prolonged time (14 days). Blood samples for hemoglobin, $\mathrm{pH}$, lactate, bicarbonate and creatinine were drawn prior to the induction of shock and $24 \mathrm{~h}$ after resuscitation. Five days after resuscitation the animals were sacrificed, and liver, lung and kidney histology was examined. Results: At $24 \mathrm{~h}$ after bleeding, the hemoglobin levels decreased by 3.2 and $1.7 \mathrm{~g} / \mathrm{dl}$, the $\mathrm{pH}$ decreased by 0.008 and 0.001 , while the lactate levels increased by 1.6 and $2.7 \mathrm{mg} / \mathrm{dl}$ in the fresh and old blood resuscitation groups, respectively, with no significant difference between the groups. A trend toward more severe renal damage occurred in the old compared to the fresh blood resuscitation group $(p=0.089)$. Conclusion: The results of the present study show that in this animal model of hemorrhagic shock the duration of storage of RBCs used for transfusion did not affect the outcome of resuscitation.

*These authors contributed equally to this work.

\section{Schlüsselwörter \\ Transfusion · Lagerungsdauer · Schock · Reanimation}

\section{Zusammenfassung}

Erythrozytentransfusionen sind bei hämorrhagischem Schock lebensrettend. Andererseits haben verschiedene klinische Studien gezeigt, dass Bluttransfusionen bei schwer kranken Patienten mit unerwünschten Nebenwirkungen einhergehen können. Außerdem wurde ein Zusammenhang zwischen größerer Lagerungsdauer und unerwünschten Nebenwirkungen der Erythrozytentransfusion postuliert. Das Zie dieser Studie ist es, in einem Tiermodell für den hämorrhagischen Schock den Effekt der Blutlagerungsdauer auf den Reanimationserfolg zu untersuchen. Methoden: Bei 20 Wistar-Ratten wurden eine Venaesectio vorgenommen, um einen reversiblen hämorrhagischen Schock auszulösen. Die Hälfte der Ratten wurde mit Blut reanimiert, das nur kurze Zeit (4 Tage) gelagert worden war, die andere Hälfte erhielt während der Reanimation Blut, das bereits längere Zeit (14 Tage) gelagert worden war. Blutproben wurden vor und $24 \mathrm{~h}$ nach Einleitung des Schocks entnommen und auf Hämoglobin. $\mathrm{pH}$, Laktat, Bikarbonat und Kreatinin untersucht. Fünf Tage nach der Reanimation wurden die Tiere getötet und deren Leber, Lunge und Niere histologisch untersucht. Ergebnisse: In den Frischblut- bzw. Altblutreanimationsgruppen waren $24 \mathrm{~h}$ nach der Blutung die Hämoglobinkonzentrationen um 3,2 bzw. 1,7 g/dl gesunken und der $\mathrm{pH}$ um 0,008 bzw. 0,001, während die Laktatwerte um 1,6 bzw. 2,7 mg/dl zunahmen; keiner dieser Unterschiede zwischen den Gruppen war signifikant. Lediglich ein Trend zu einer stärkeren renalen Schädigung war in der Gruppe zu beobachten, die mit alten Blut reanimiert wurde $(p=0,089)$. Schlussfolgerung: Die Ergebnisse der vorliegenden Studie zeigen, dass in einem Tiermodell des hämorrhagischen Schocks die Lagerungsdauer der transfundierten Erythrozyten das Erfolg der Reanimation nicht beeinflusst.

\begin{tabular}{|c|c|}
\hline KARGER & (C) 2011 S. Karger GmbH, Freiburg \\
\hline $\begin{array}{l}\text { Fax +497614520714 } \\
\text { Information@Karger.de } \\
\text { www.karger.com }\end{array}$ & $\begin{array}{l}\text { Accessible online at: } \\
\text { www.karger.com/tmh }\end{array}$ \\
\hline
\end{tabular}

Martin H. Ellis MD

Hematology Institute

Meir Medical Center

59 Tchernichovsky Street, Kfar Saba 44281, Israel

Tel. +972 9 7471-045, Fax -295

martinel@clalit.org.il 


\section{Introduction}

Red blood cell (RBC) transfusion is a life-saving procedure in patients with severe hemorrhage. The principal aim of blood transfusion is to increase tissue oxygenation. During storage RBCs undergo mechanical and biochemical changes affecting their ability to deliver oxygen to tissues $[1,2]$. In addition during storage accumulation of biological byproducts occur which may adversely affect the recipient of the blood product [1]. Several clinical trials have shown an association between blood transfusion and increased morbidity and mortality in critically ill patients [3]. Furthermore, there is possibly an association between prolonged blood storage and adverse outcome. However, these studies are observational and thus potentially biased by number of diseases and treatment-related variables inherently present in these patients $[4,5]$. In light of the difficulty in conducting a randomized prospective trial of short versus prolonged RBC storage in patients with hemorrhagic shock, we attempted to address the question using an animal model.

\section{Material and Methods}

The study was approved by the ethical committee for animal experimentation of our institution. 20 Wistar rats $(250-300 \mathrm{~g})$ were studied. They were housed according to the guide for the care and use of laboratory animals (NIH publication \#85-23, 1985). The animals were operated on under general anesthesia induced by intraperitoneal injection of xylazine and ketamine. After anesthesia the femoral vein was cannulated with a 20 gauge polytetraflouroethylene catheter (Venflon, Helsingborg, Sweden), that was fixed with a 3.0 silk suture. The catheter was flushed with a diluted heparin solution (Baxter Pharmaceuticals, Deerfield, IL, USA) at a concentration of $1 \mathrm{U} / \mathrm{ml}$.

The animals then underwent a $5 \mathrm{ml}$ phlebotomy which represented $33-40 \%$ of their total blood volume of $12-15 \mathrm{ml}$. A pilot study confirmed that this volume depletion resulted in reversible hemorrhagic shock. The animals were maintained in a state of hypovolemic shock for $30 \mathrm{~min}$ and were randomized to two groups: 10 rats were transfused with $5 \mathrm{ml}$ of rat blood that had been stored for 4 days in $0.625 \mathrm{ml}$ citrate, phosphate, dextrose, adenine (CPDA-1; Teva Medical, Ashdod, Israel) solution, termed 'fresh blood', and 10 rats were transfused with $5 \mathrm{ml}$ of rat blood that had been stored for 10-14 days in $0.625 \mathrm{ml}$ CPDA-1, termed 'old blood'. The blood for transfusion was procured from donor Wistar rats that were not included in the experiment. Storage of rat blood for up to 4 days is equivalent to storage of human blood for 14 days and is considered 'fresh blood' and storage of rat blood for 10-14 days is the equivalent to storage of human blood for 28-35 days and is considered 'old blood' [6]. Blood pressure and heart rate were measured continuously from prior to phlebotomy until after completion of the resuscitation Blood samples were drawn via the femoral vein and analyzed for $\mathrm{pH}$, lactate, bicarbonate, hemoglobin and creatinine prior to phlebotomy and $24 \mathrm{~h}$ after resuscitation.

After resuscitation the animals were maintained for 5 days. They were then sacrificed, and the lungs, liver and kidneys were harvested. The samples underwent overnight fixation in a $4 \%$ formaldehyde solution and serial $5 \mu \mathrm{m}$ sections were prepared after the samples were dehydrated in graded ethanol solutions, cleared in xylene and embedded in paraffin. The sections were attached to slides and stained with hematoxylin and eosin. Histological examination of the kidney, lung and liver was per-
Table 1. Changes observed in laboratory results at 24 hours after resuscitation compared to baseline values

\begin{tabular}{lccc}
\hline & $\begin{array}{c}\text { 'Fresh' blood } \\
\text { resuscitation }\end{array}$ & $\begin{array}{c}\text { 'Prolonged' blood } \\
\text { resuscitation }\end{array}$ & p value \\
\hline Hemoglobin, g/dl & $-3.2 \pm 2.7$ & $-1.7 \pm 1.5$ & 0.032 \\
$\mathrm{pH}$ & $0.008 \pm 0.13$ & $0.01 \pm 0.05$ & 0.136 \\
Lactate, $\mathrm{mg} / \mathrm{dl}$ & $16 \pm 29.3$ & $2.7 \pm 6$ & 0.274 \\
Bicarbonate, $\mathrm{mmol} / \mathrm{l}$ & $3.4 \pm 3.5$ & $2.8 \pm 3.5$ & 0.465 \\
Creatinine, $\mathrm{mg} / \mathrm{dl}$ & $-0.05 \pm 0.14$ & $-0.05 \pm 0.16$ & 0.549 \\
\hline
\end{tabular}

Table 2. Histologic score (mean \pm standard deviation) of kidney and lung tissue on day 5 after induction of hemorrhagic shock

\begin{tabular}{llll}
\hline & $\begin{array}{c}\text { 'Fresh' blood } \\
\text { resuscitation }\end{array}$ & $\begin{array}{c}\text { 'Prolonged' blood } \\
\text { resuscitation }\end{array}$ & p value \\
\hline Renal histological score & $1.8 \pm 1.5$ & $3 \pm 0.8$ & 0.079 \\
Lung histological score & $4.1 \pm 2.2$ & $4.1 \pm 1.6$ & 0.447 \\
\hline
\end{tabular}

formed by a pathologist who was blinded to the treatment arms. The morphological evaluation of the hematoxylin-eosin stains was based on rating scales for each organ. Lungs were rated on a scale from 0 to 18 based on Tiefenburn et al. [7], evaluating the severity of atelectasis, hemorrhage, edema, congestion, inflammation and hyperaeration. Liver damage was evaluated on a scale of 0 to 12 according to Suzuki et al. [8], based on the degree of congestion, necrosis and formation of vacuoles. Kidneys were rated according to Dobyan et al. [9] on a scale of 0 to 18 , for swelling and flattening of epithelial cells, tubular dilatation, edema, microthrombi and acute tubular necrosis.

\section{Statistical Analysis}

Data was analyzed using non-parametric Kruskal-Wallis one-way analysis by ranks. All p values were two sided; a p value of less then 0.05 was considered to indicate statistical significance. Analyses were performed using SPSS software version 18 .

\section{Results}

Four rats could not be included in the analysis: 3 rats in the 'fresh' blood group died immediately after phlebotomy and $1 \mathrm{rat}$ in the 'old blood' group died $24 \mathrm{~h}$ after phlebotomy.

The changes in the laboratory indices that were examined $24 \mathrm{~h}$ after phlebotomy are presented in table 1 . Mean reduction in hemoglobin at $24 \mathrm{~h}$ was $3.2 \pm 2.7$ and $1.7 \pm 1.5 \mathrm{~g} / \mathrm{dl}$, in the 'fresh' blood resuscitation and 'old' blood resuscitation groups respectively $(\mathrm{p}=0.032)$. Mean serum creatinine decreased at $24 \mathrm{~h}$ by $0.05 \pm 0.14$ and $0.05 \pm 0.16 \mathrm{mg} / \mathrm{dl}$ in the 'fresh' and 'old' blood resuscitation groups respectively $(\mathrm{p}=0.549)$. The $\mathrm{pH}$ decreased by $0.008 \pm 0.13$ and $0.01 \pm 0.05$ in the 'fresh' and 'old' blood resuscitation groups respectively $(\mathrm{p}=0.136)$.

Mean serum bicarbonate levels decreased by $3.4 \pm 3.5$, and $2.8 \pm 3.5 \mathrm{mmol} / \mathrm{l}$ in the 'fresh' and 'old' blood resuscitation groups respectively $(\mathrm{p}=0.465)$, while mean lactate levels at $24 \mathrm{~h}$ 


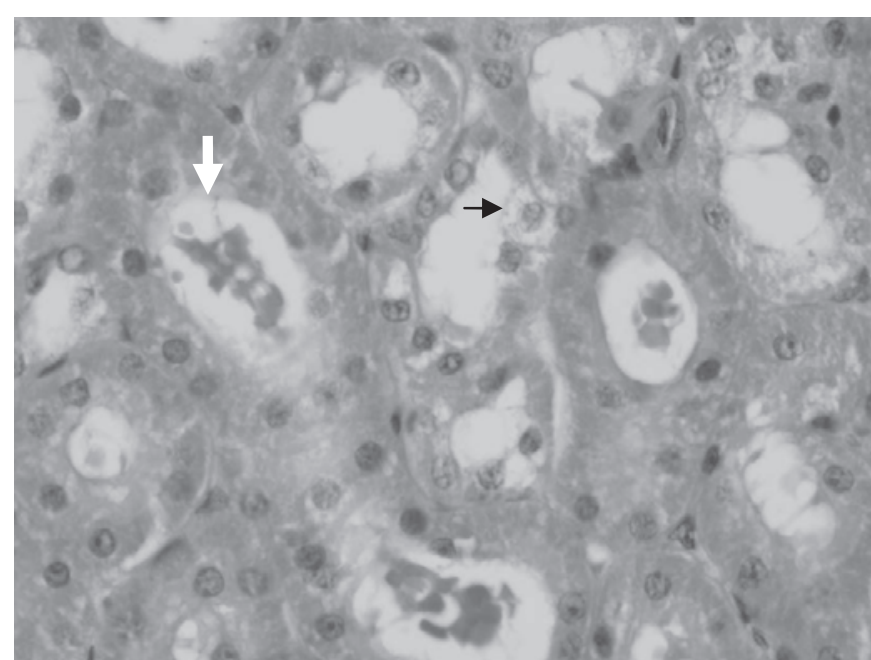

Fig. 1. Kidney histology in a rat 5 days after induction of hemorrhagic shock. Tubular dilatation (white arrow), and swelling of tubular epithelium (black arrow) are noted.

increased by $16 \pm 29.3$, and $2.7 \pm 6 \mathrm{mg} / \mathrm{dl}$ in the 'fresh' and 'old' blood resuscitation groups respectively $(\mathrm{p}=0.274)$.

Histological examination of the lungs and kidneys showed some of the typical changes described in hemorrhagic shock, including epithelial swelling and tubular dilatation in the kidneys (fig. 1) as well as congestion and hyperaeration in the lungs (fig. 2). There were minimal changes in liver histology, and scoring was not relevant. Kidney histological score was $1.8 \pm 1.5$ and $3 \pm 0.8$ in the 'fresh' and 'old' blood groups respectively, with a trend toward more severe renal damage in the 'old' blood group compared to the 'fresh' blood group, although without statistical significance $(\mathrm{p}=0.089)$. Lung histological score was $4.1 \pm 2.2$ and $4.1 \pm 1.6$ in the 'fresh' and 'old' blood groups respectively $(\mathrm{p}=0.364)$ (table 2$)$.

\section{Discussion}

In this paper we report the results of an animal model of hemorrhagic shock treated with rat RBCs stored for a prolonged or a short period. There was no overall survival difference between the two groups at the end of the 5-day study period. Three rats died during the induction of hemorrhagic shock, and only one other animal died during the study period. In this subject laboratory samples prior to death were not obtained and organ histology could not be assessed because of post mortem autolytic changes.

Histological grading of the kidneys showed a trend toward increased tissue damage among animals treated with 'prolonged' blood storage, compared to those treated with 'fresh' blood; however, this trend did not achieve statistical significance. Liver and lung damage as determined by a standard histological score did not differ between the treatment groups.

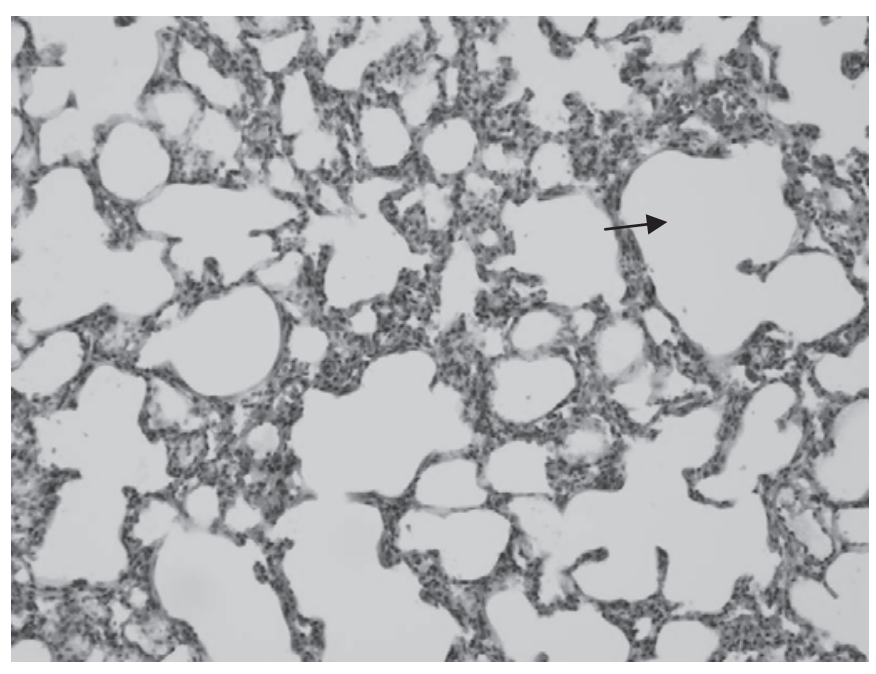

Fig. 2. Histology of lung tissue 5 days after induction of hemorrhagic shock. Hyperaeration is shown by dilatation of alveolar spaces (black arrow), with thinning and rupture of alveolar septae. Congestion is evident with engorgement of blood vessels and mild interstitial hemorrhage.

Furthermore, laboratory parameters indicating tissue damage, particularly acidosis and renal function were identical in the groups.

The aim of blood transfusion is to increase oxygen delivery to tissues by increasing hemoglobin concentration. Prolonged storage of blood causes physical and biochemical changes to RBCs that are generally known as 'storage lesions' $[1,2]$. These may impair oxygen delivery and have been claimed to cause adverse effects in the recipient.

RBC aging may impair the ability of oxygen delivery to tissues because of abnormalities in hemoglobin-oxygen dissociation: in stored blood, the hemoglobin dissociation curve may be right-shifted due to acidosis and decreased intracellular 2,3-DPG, which impairs oxygen dissociation in tissues and aggravates tissue hypoxia. Storage of RBCs leads to biochemical changes in the RBCs, including ATP depletion and reduced membrane deformability, which may impair the cell's ability to traverse capillaries in the microcirculation and further compromise oxygen delivery.

Prolonged storage also increase interactions between the RBCs and endothelial cells which further impair the RBC's ability to traverse the microcirculation [10].

Clinical data that has accumulated recently suggest that transfusion of blood in a number of clinical settings may be associated with increased morbidity and mortality. It has been suggested that the adverse effects of transfusion, including increased mortality, serious infections, multiorgan failure and duration of hospital admission $[4,5,11]$, are related to prolonged blood storage prior to transfusion. However, these data are derived from retrospective and observational studies, with no study having being designed and conducted prospectively to evaluate the impact of blood storage duration on the clinical outcome. 
One of the pivotal trials demonstrating the adverse effects of transfusion was the TRICC study which examined the effect of blood transfusions in critically ill patients [3]. Patients were randomly assigned to receive blood transfusions according to a restrictive (hemoglobin $<7 \mathrm{~g} / \mathrm{dl}$ ) or non-restrictive threshold (hemoglobin $<10 \mathrm{~g} / \mathrm{dl}$ ). The results showed that patients allocated to the restrictive transfusion group received fewer units of blood and had a lower incidence of respiratory failure and improved survival. This important study however, was not designed to compare blood storage time.

A prospective database of trauma patients was used to compare patients who developed multiorgan failure after receiving 6-20 units of RBCs to a control group without multiorgan failure. Patients who developed multiorgan failure were found to have received blood that had been stored for a longer period than the blood transfused in the control group. Multivariate analysis identified mean age of blood units, number of units older than 14 days and number of units older than 21 days as independent risk factors for multiorgan failure [11].

One retrospective trial examining morbidity and mortality in 321 patients after cardiac surgery found that the duration of blood storage was an independent risk factor for inhospital mortality, acute renal failure and intensive care unit admission time [5]. In another such study, Koch et al. [12] reported on subjects undergoing coronary artery bypass grafting, heart valve surgery or both. They found that subjects transfused with RBCunits older than the median storage duration of 14 days, were more likely to die in the hospital, require prolonged ventilation and had higher rates of sepsis and renal failure than subjects receiving newer blood. Although the pool of subjects was very large $-6,000$ subjects - , the data were obtained from only center and had several limitations, namely that the clinical characteristics of the patients and the ABO type of RBCs received were not entirely similar between the two patient groups. Thus uncertainty remains regarding the clinical importance of RBC storage duration and exactly what defines 'newer' versus 'older' blood.

A possible explanation for the adverse effects presumed to be related to increased duration of blood storage is the progressive accumulation of proinflammatory cytokines during storage. Infusion of these cytokines may initiate an inflammatory cascade or may alter immune response. This may predispose critically ill patients to systemic inflammatory response syndrome (SIRS) or cause susceptibility to severe infections [13].

In addition, prolonged storage increases the concentration of free hemoglobin in blood units. Free hemoglobin binds and inactivates nitric oxide. This may cause vasoconstriction and thrombosis which may aggravate tissue ischemia [14].

In our study the only adverse effect of prolonged storage of transfused RBCs was a trend toward increased renal damage. These results are in contrast to suggestions in the literature presented above, purporting a correlation between prolonged blood storage and adverse clinical outcome. Several factors may explain these differences. The potential adverse effect of prolonged storage may become evident only in specific clinical situations such as critically ill patients in an intensive care unit in whom an inflammatory response to underlying illness or trauma may have already occurred at the time of transfusion. In addition, the reports linking duration of blood storage with adverse clinical outcome are retrospective; a prospective randomized study has not been performed to address this question specifically. Thus factors such as publication bias in the introduction of confounding variables in these reports need to be considered when evaluating their conclusions. Furthermore, not all studies have shown a correlation between duration of blood storage and adverse outcomes [15].

Another possible explanation for the apparent inconsistency between our results and those published in the literature may relate to the specific animal model that we used in this study which may not reflect the biologic complexity of hemorrhagic shock in the clinical situation. Finally, it should be noted that the rats receiving 'fresh' blood had a greater reduction in hemoglobin concentration $24 \mathrm{~h}$ after phlebotomy than those receiving 'old' blood $(3.2 \pm 2.7$ vs. $1.7 \pm 1.5 \mathrm{~g} / \mathrm{dl}(\mathrm{p}=0.032))$. However, we do not believe that this inadvertent difference between the groups influenced the outcome of the study because, despite this varying hemoglobin levels, there was no difference between the groups with regard to measurement of tissue perfusion such as $\mathrm{pH}$, serum bicarbonate and serum creatinine levels.

While acknowledging that in cases of massive hemorrhage after surgery or trauma in humans numerous factors influence patient outcome, the results of our study suggest that, at least in an animal model, duration of RBC storage may not be causally linked to adverse clinical outcomes and that appropriately designed prospective trials should be performed to answer this important question. Until such data is available, 'fresh' RBC units should not be considered to be the product of choice in the treatment of hemorrhagic shock.

\section{Disclosure Statement}

The authors have no conflict of interest to declare. 


\section{References}

1 Tinmouth A, Fergusson D, Yee IC, Hébert PC ABLE Investigators; Canadian Critical Care Trials Group: Clinical consequences of red cell storage in the critically ill. Transfusion 2006;46:2014-2027.

2 Zubair AC: Clinical impact of blood storage lesions. Am J Hematol 2010;85:117-122.

$>3$ Hébert PC, Wells G, Blajchman MA, Marshall J, Martin C, Pagliarello G, Tweeddale M, Schweitzer I, Yetisir E: A multicenter, randomized, controlled clinical trial of transfusion requirements in critical care. Transfusion Requirements in Critical Care Investigators, Canadian Critical Care Trials Group. N Engl J Med 1999;340:409-417.

4 Purdy FR, Tweeddale MG, Merrick PM: Association of mortality with age of blood transfused in septic ICU patients. Can J Anaesth 1997;44:12561261.

5 Basran S, Frumento RJ, Cohen A, Lee S, Du Y, Kaplan HS, Stafford-Smith M, Bennett-Guerrero E: The association between duration of storage of transfused red blood cells and morbidity and mortality after reoperative cardiac surgery. Anesth Analg 2006;103:15-20.
6 d'Almeida MS, Jagger J, Duggan M, White M, Ellis C, Chin-Yee IH: A comparison of biochemical and functional alterations of rat and human erythrocytes stored in CPDA-1 for 29 days: implications for animal models of transfusion. Transfus Med 2000;10:291-303.

7 Tiefenbrun J, Dikman S, Shoemaker WC: The correlation of sequential changes in the distribution of pulmonary blood flow in hemorrhagic shock with histopathologic anatomy. Surgery 1975;78:618-627.

8 Suzuki H, Mizuno H, Tominaga T: Studies on the incidence of hepatocellular carcinoma in heavy drinkers with liver cirrhosis. Alcohol Alcohol 1993; (suppl 1B):109-114.

9 Dobyan DC, Nagle RB, Bulger RE: Hypovolemic model of acute tubular necrosis in rat kidney. Virchows Arch B Cell Pathol 1977;25:271-280.

10 Chin-Yee I, Statchuk L, Milkovich S, et al: Transfusion of red blood cells under shock conditions in the rat microvasculature. Blood 2004;104:2713A.
1 Zallen G, Offner PJ, Moore EE, Blackwell J, Ciesla DJ, Gabriel J, Denny C, Silliman CC: Age of transfused blood is an independent risk factor for post injury multiple organ failure. Am J Surg 1999;178:570-572.

12 Koch CG, Li L, Sessler DI, Figueroa P, Hoelte GA, Mihaljevic T, Blackstone EH: Duration of red cell storage and complications after cardiac surgery. N Engl J Med 2008;358:1229-1239.

13 Kristiansson M, Soop M, Saraste L, Sundkvist SJ Cytokines in stored red blood cell concentrates: promoters of systemic inflammation and simulators of acute transfusion reactions? Acta Anaesthesiol Scand 1996;40:496-501.

14 Reynolds JD, Ahearn GS, Angelo M, Zhang J, Cobb F, Stamler JS: S-nitrosohemoglobin deficiency: a mechanism for loss of physiological activity in banked blood. Proc Natl Acad Sci U S A 2007;104:17058-17062.

15 Yap CH, Lau L, Krishnaswamy M, Gaskell M, Yii M: Age of transfused red cells and early outcomes after cardiac surgery. Ann Thorac Surg 2008;86: 554-559. 